\title{
"Syndrome of Contractures and Deformities" According to Prof. Hans Mau as the Primary Cause of Hip, Neck, Shank and Spine Deformities in Babies, Youth and Adults
}

\author{
Karski Tomasz ${ }^{1}$, Karski Jacek ${ }^{2}$ \\ Vincent Pol University in Lublin \\ Medical University in Lublin
}

\begin{abstract}
It has been observed that the Syndrome of Contractures and Deformities (SofCD) is the causal influence of malformations in locomotor's system in children and the insufficiency and pain in adults patients. According to Prof. Hans Mau there exists a list of symptoms in newborns and babies. He describes this syndrome as 'the Seven Contracture Syndrome' (in German "Siebenersyndrom"). In the article the 8-th deformity, namely the varus deformity of shanks, is described by the authors in 2006. The article thoroughly presents the Syndrome of Contractures and Deformities and its influence to development of hip dysplasia, as the primary cause of wry neck (torticollis) and one of the four causes of Blount disease. Additionally, the explanation of the biomechanical etiology of the so-called idiopathic scoliosis is also provided.
\end{abstract}

Keywords: contracture, incorrect position of the body, influence on the neck, spine, hips and shank. Therapy. Prophylaxis.

\section{INTRODUCTION}

In orthopaedic literature mainly deals with deformities in children, and with pain in adults patients. Most authors discuss the problems in the context of muscle weakness. Our long lasting (1995 - 2015) clinical observations, prove that the problem of deformity in children and pain in adults patients is not connected with "muscle weakness" but with the asymmetric or symmetric shortening of soft tissues - muscle, tendons, capsules in the regions of spine, hips, knees, feet.

\section{CAuses OF „SYNDROME OF CONTRACTURE` (SOFC)}

The „syndrome of contractures” (Fig. 1) has been described primarily by Prof. Hans Mau - as syndrome of seven contractures [German - Siebener [Kontrakturen] Syndrom"] This syndrome has been also described by: Hensinger, Howorth, Green \& Griffin, Dega, Vizkelety, Karski J., Karski T., M. Tarczyńska, J. Kałakucki and others authors (1 to 21). The cause of the "syndrome of contractures" is related with foetal period of life, if the body of foetus is heavier, or longer than average and there were maternal conditions like: small belly during pregnancy, lack of amniotic fluids (oligohydramion), "androidal" or "platypeloidal" pelvic bone anatomy. In the asymmetrical contractures of joints also CNS constitutes an additional cause. The left sided "Syndrome of Contractures" is more common, as the result of first position of the foetus during pregnancy (left sided), which occurs in $85 \%-95 \%$ of cephalic presentation pregnancies (Oleszczuk). In cases of "Syndrome of Contractures" infantile scoliosis, torticollis and limitation of abduction of left hip, later dysplasia are frequently observed (Fig. 2).

${ }^{1}$ Corresponding Author: tmkarski@gmail.com 


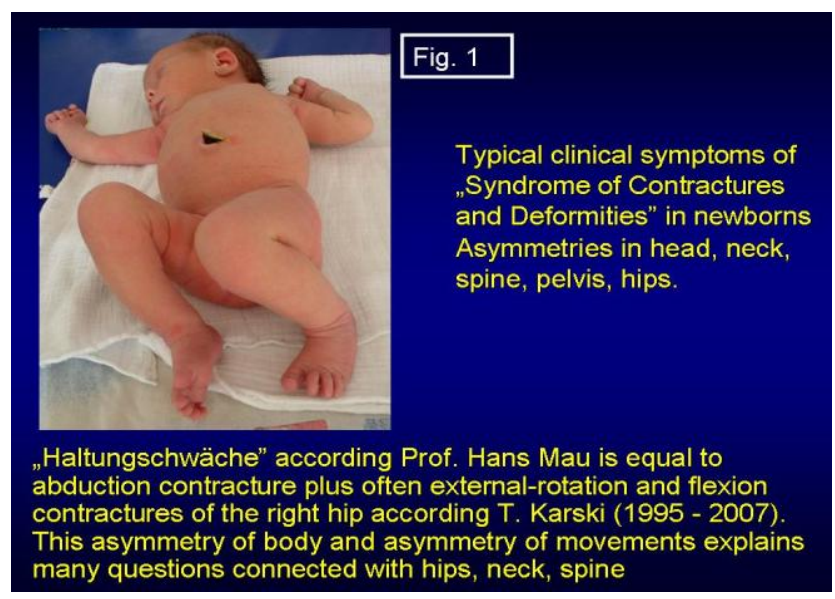

Fig.1. Typical clinical symptoms of the "Syndrome of contractures and Deformities” in newborns and in babies. Asymmetries in the head, neck, spine, hips (later dysplasia), pelvis. „Haltungschwäche according Hans Mau is equal to abduction contracture plus often external-rotation and flexion contractures of the right hip (T. Karski1995 - 2007). This phenomenon explains many questions concerning so-called idiopathic scoliosis unanswered till 1995 and for other deformities.

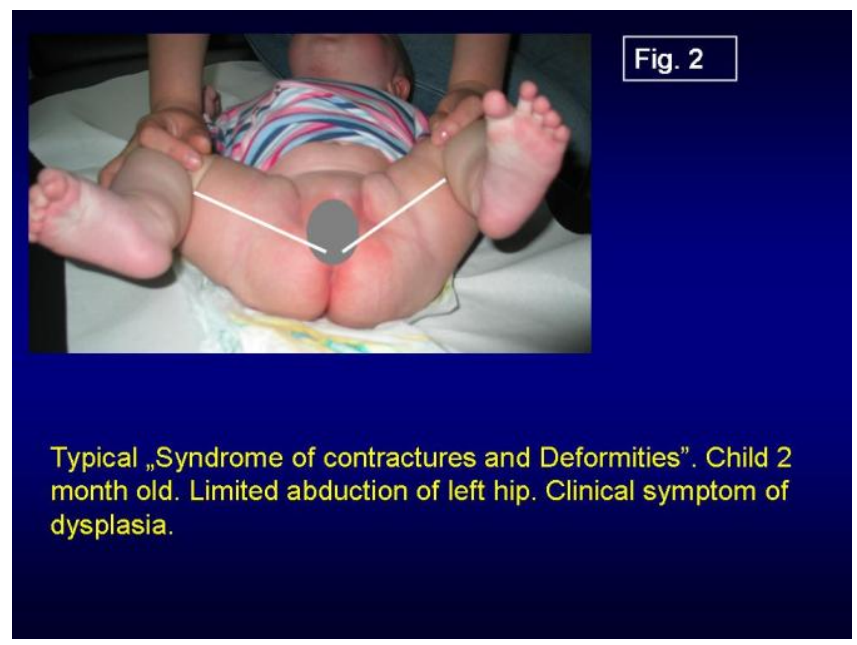

Fig.2. Typical ,Syndrome of contractures and Deformities”. Limited abduction of the left hip - clinical symptom of hip dysplasia.

\subsection{Clinical Symptoms of the "Syndrome of Contractures" According to Mau (Fig. 1, 2, 8)}

$>$ scull deformity (plagiocephaly),

torticollis muscularis (wry neck),

$>$ scoliosis infantilis (infantile scoliosis) - other than idiopathic scoliosis,

$>$ Contracture (shortening) of adductor muscles of the left hip. Untreated contracture can lead to the developmental dysplasia of the hip (DDH according to Klisič),

$>$ Contracture (shortening) of abductor muscles and soft tissues of the right hip (according to T. Karski), described as Haltungsschwäche ("weak posture") by $\mathrm{H}$. Mau. With time, these asymmetries in hips region cause asymmetry of gait and loading; causing so called idiopathic scoliosis (T. Karski 1995-2007);

$>$ pelvic bone asymmetry - the oblique pelvis positioning visible in X-ray examination for hip joint screening [see above points $4 \& 5$ ];

$>$ Foot deformities - such as: pes equino-varus, pes equino-valgus, pes calcaneo-valgus.

$>$ In Lublin, the list of deformities belonging to the "Syndrome of Contractures" also includes deformities in shanks in newborn and babies (2006 T. Karski). This excessive shank deformity (crura vara) later can lead under special circumstances to Blount disease [T. Karski, J. Karski and others - 2006, Orthopädische Praxis]. Since then we talk about "Syndrome of Contractures and Deformities" (SofCD). 


\section{Material}

In the years 2005 - 2013 authors examined 818 newborns and babies with signs of "Syndrome of Contractures and Deformities". The control group of 212 children presented by parents for examination, showed no signs of SofCD.

Syndrome of Contractures and Deformities and its influence on locomotors system in youth and adults. In the article we present cases of SofCD and its influence on: (1) hip dysplasia, (2) Blount disease, (3) wry neck (torticollis), and we also present (4) biomechanical aetiology of the so-called idiopathic scoliosis.

\section{HIPS}

The dysplasia of the hips can be connected with a/ Syndrome of Contractures and Deformities (SofCD), with $\mathbf{b} /$ laxity of joints and with c/ disorders of central nerve system. The dysplasia of the hips in SofCD shown in babies is the result of lack of abduction of hip, mostly left hip (Fig. 2). The treatment in this group of deformation is simply, easy and gives good results. In therapy it is important to use the permanent, longer than one year, physiological carrying of the child in full abduction and flexion of the hips (Fig. 3a, 3b) as opposed to carrying the child incorrectly, without abduction of the hips, with the child facing directed forward. Such way of incorrect carrying is often recommended in our country by "over educated" physiotherapies and orthopaedic surgeons (Fig. 4a, 4b). If dysplasia of the hips in not cured sufficiently in the period of the first year of life - for prolonged therapy we use: Weickert treasures - the model for walking or spongy triangle for walking. These orthopaedic devices for walking and standing in abduction bring better results than those for lying.

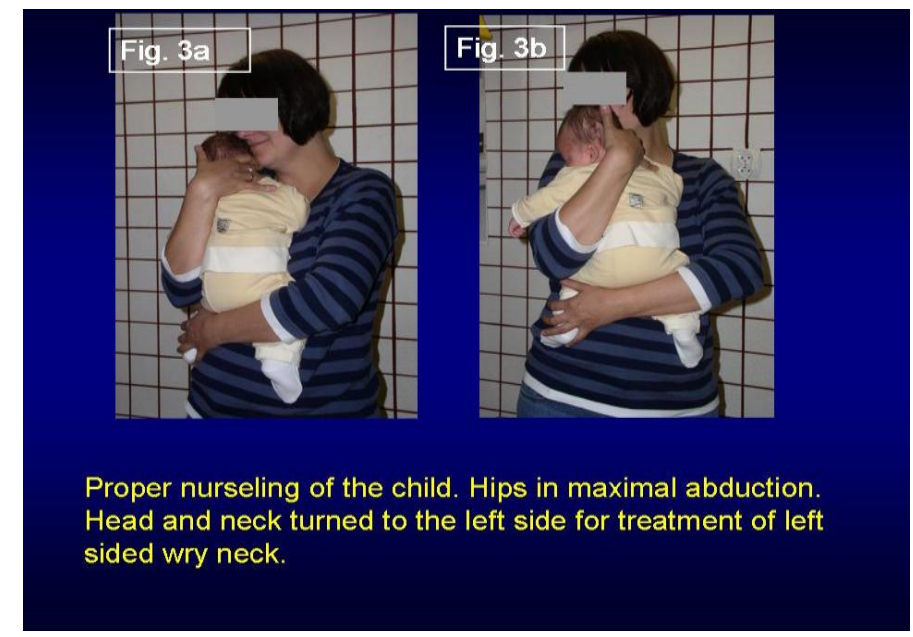

Fig.3a, 3b. Proper nurseling of the child. Hips in maximal abduction. Head and neck turned to the left side for treatment of left sided wry neck.

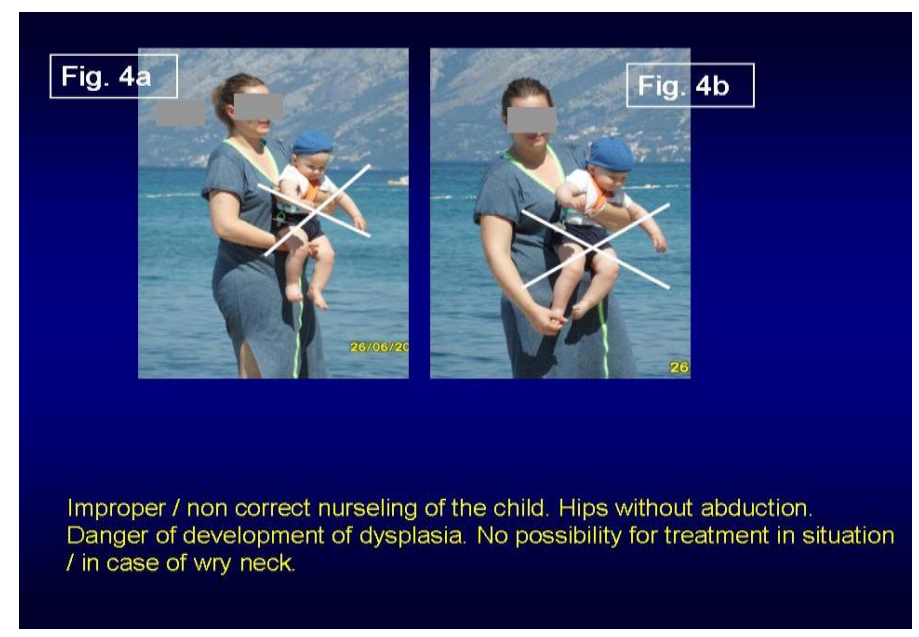

Fig.4a, 4b. Improper / non correct nurseling of the child. Hips without abduction. Danger of development of dysplasia. No possibility for treatment in case of wry neck. 
American Research Journal of Medicine And Surgery, Volume 1, Issue 2, 2015 ISSN 2379-8955

\section{NECK}

Wry neck is a very common deformity (6\% to $8 \%$ of Polish population) in newborns and babies (Fig. 3a, 3b, 5a, $\mathbf{5 b}, \mathbf{5 c}, \mathbf{6 a}, \mathbf{6 b}, \mathbf{7} \mathbf{a}, \mathbf{7 b})$ - in Latin - torticollis muscularis or torticollis myogenes. There are three forms of such deformity:

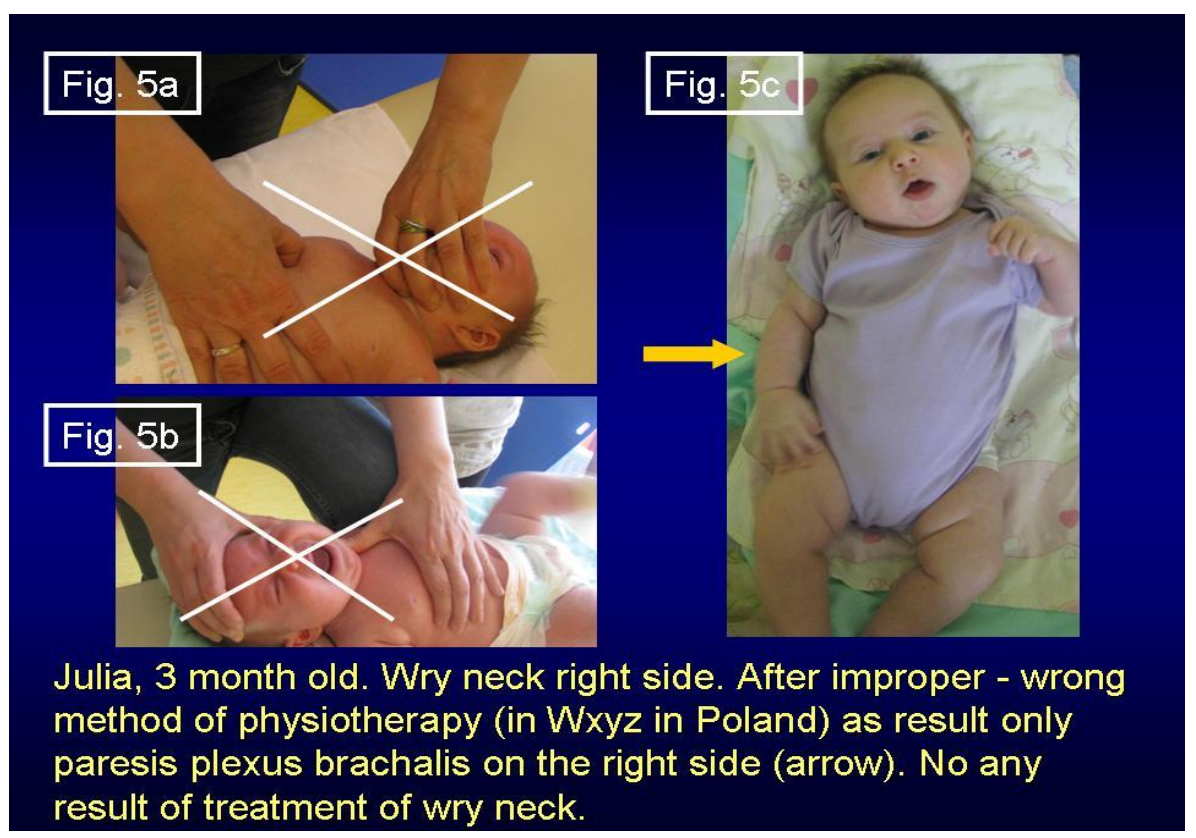

Fig. 5a, 5b, 5c. Julia. 3 month old. Wry neck right side. Improper - wrong method of physiotherapy in one of Centres of Rehabilitation in Poland (Fig. 5a, 5b). In result only paresis plexus brachalis on the right side (Fig. $5 c$ arrow). No any result of treatment of wry neck.

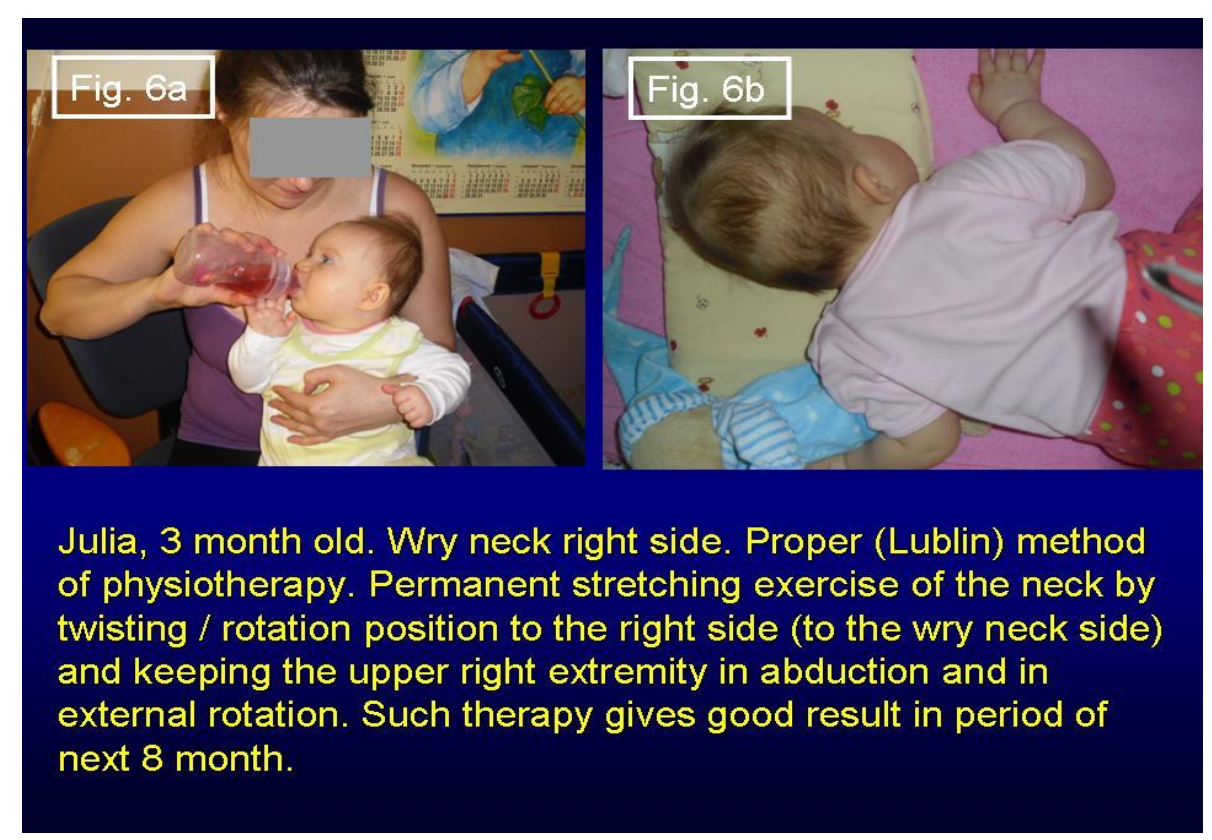

Fig. 6, 6b Julia. proper method of physiotherapy in Lublin. Permanent stretching exercise of the head and neck by twisting to the right side and keeping upper right extremity in abduction and in external rotation. Such therapy gives good result in the period of 8 month. 


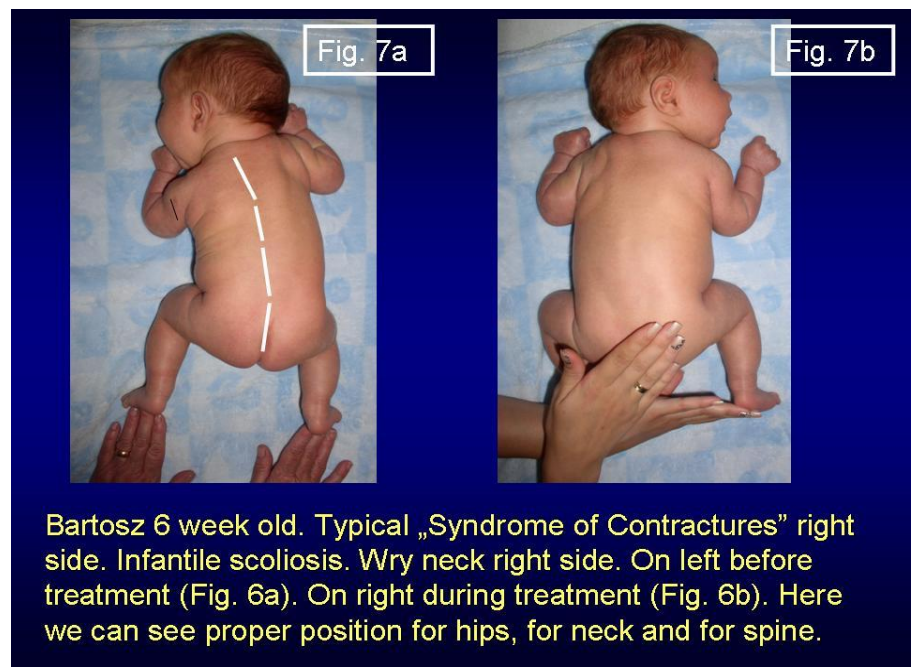

Fig. 7a, 7b. Bartosz 6 weeks old. Typical "Syndrome of Contractures and Deformities” of the right side. Infantile scoliosis. Wry neck right side. Picture on the left-before treatment (Fig. 7a). Picture on right-during treatment (Fig. 6b). Proper position for hips, for neck and for spine.

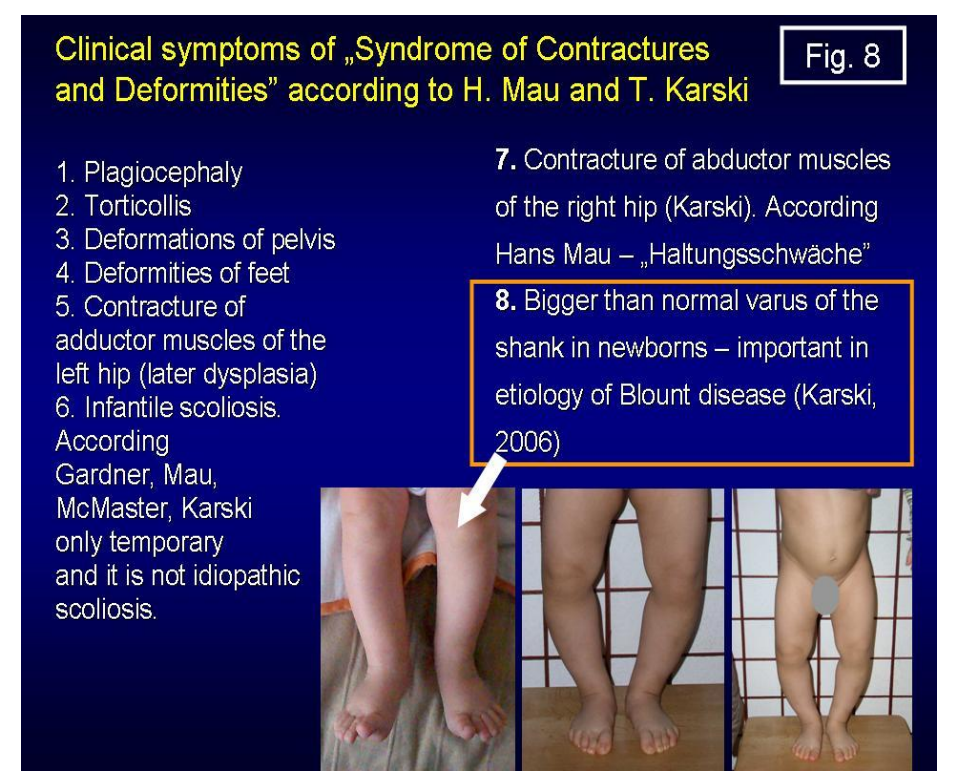

Fig. 8. The list of clinical symptoms of ,Syndrome of Contractures and Deformities” according to H. Mau and T. Karski with presentation of crus varum both sides.

a/ connected with SofCD

b/ post-traumatic delivery

c/ congenital wry neck with tumour neonaorum

The treatment of wry neck in our country is frequently performed by an old method. Doctors recommend to keep the child's head directed to the other side than wry neck. Such old physiotherapy never gives sufficient results. The proper treatment is only by physiotherapy relying on permanent "rotation stretching" - that is - the head is turned to the torticollis side [!] (Fig. 6a, 6b, 7b). This method of therapy was introduced in Lublin in 1974 (T. Karski publication in German in Orthopädische Praxis) and applied to children from the age of a few months to 4 years proves very successful. In the years before 1974, Paediatric Orthopaedic and Rehabilitation Department of Medical University in Lublin conducted many operations for wry neck, namely $2-3$ operations per week. After 1974 (in years 1995 - 2009 - Prof. T. Karski was the Head of this Department) we operate only $2-3$ cases per year (data from the Department's documents). Concluding it can be said that the rotation stretching with the head turned to the side of torticollis is fully successful method of treatment. 


\section{SHANK}

The varus deformity of the shank in newborns is added to the Syndrome of Contractures and Deformities in 2006 T. Karski (Fig, 8). When the varus of the shank in newborns is bigger than "normal" - Blount disease can develop in two cases: a/ when early standing and walking develops at the age of 8, 9, or 10 month and b/ when there is insufficient vitamin D supply. At the beginning the Blount disease in all cases is bilateral. In next years one shank, mostly left can be corrected spontaneously (Fig. 9a, 9b). The correction of left varus shank deformity is connected with habit of standing at ease on the right leg - see explanation the problem of standing in the next subchapter about scoliosis.

All cases of Blount disease till 1981 have been operated. It is commonly known that the deformity develops on the basis of some laws. The varus of the shank develops when this law applies that is when the child walks and stands, but this law (the Heuter Volkmann law) does not apply when the child does not walk or stand, but is carried and plays on floor - the axis of shank correct spontaneous. After 1981 the parents were advised to carry the child in age $1-3$ years with Blount disease and never let him/her stand or walk for $2-3$ month. After that time the axis of legs comes to normal in all treated cases [!]. The positive results are proved by all our patients. Our material covers more than 120 cases.

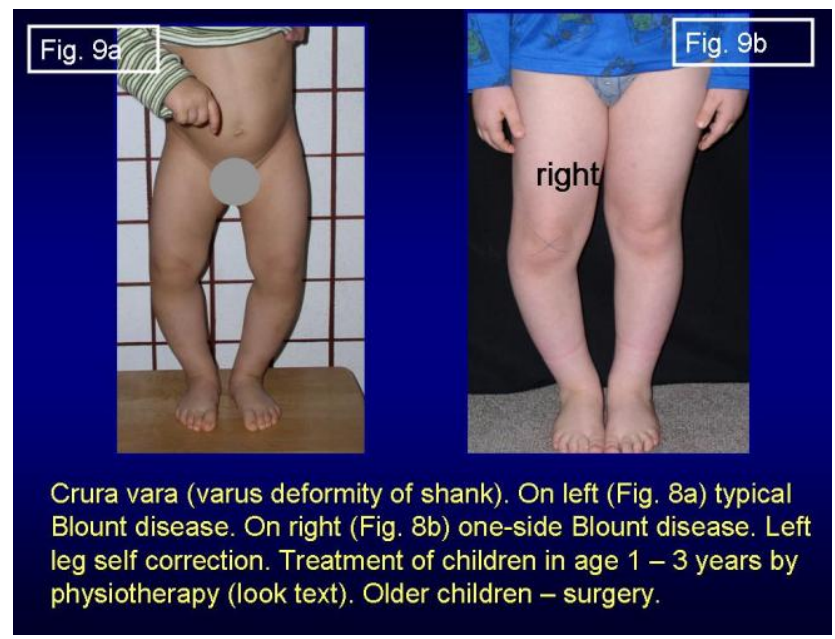

Fig. 9a, 9b. Crura vara (varus deformity of shanks). On the left (Fig. 9a) - typical Blount disease. On right (Fig. 9b) - one-sided Blount disease. Left leg self correction. Treatment of children at the age from 1 to 3 years-only by physiotherapy (look text). Older children - surgery.

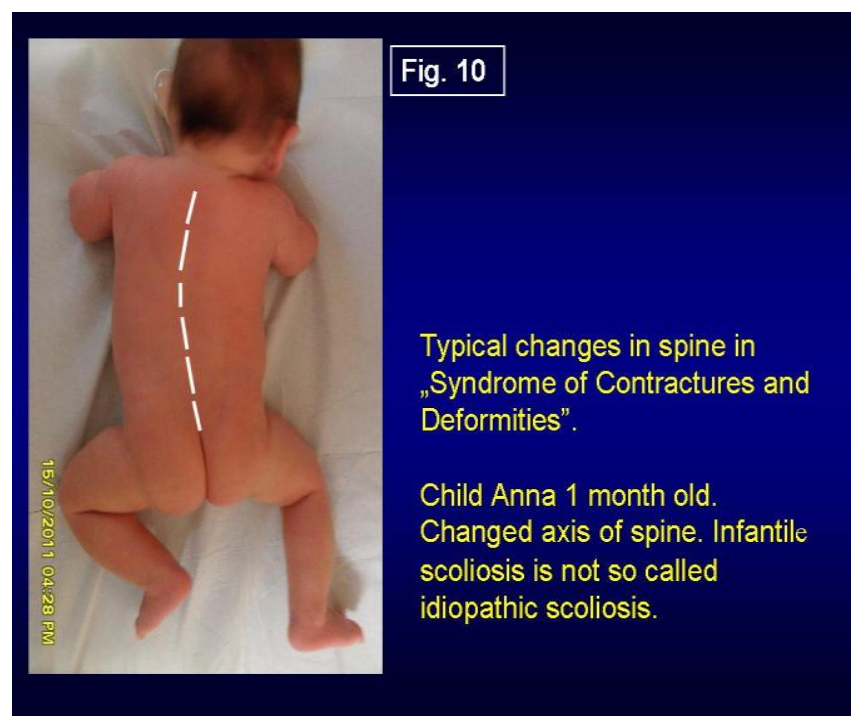

Fig. 10. An example of infantile scoliosis. Such type of spine deformity in not a case of "so called idiopathic scoliosis". This spine deformity is closely connected with "Syndrome of Contractures and Deformities" and disappears after proper nurseling. 


\section{SPINE - SCOLIOSIS}

> The biomechanical aetiology of scoliosis has been discussed and presented since 1995 (T. Karski) and now finally is accepted in many countries by many orthopaedic surgeons, rehabilitation doctors and physiotherapists.

$>$ History of discoveries.

> 1995 - First lecture about the biomechanical aetiology of scoliosis during the Orthopaedic Congress in Szeged / Hungary.

> 1997 - Discovery of the influence originating in standing 'at ease' on the right leg.

$>2001$ - First steps into the development of new classification - two groups of scoliosis (I epg and II/A/B epg groups - epg $=$ etiopathological groups).

$>\mathbf{2 0 0 4}$ - Further development of the new classification (second step) - third group of scoliosis (III epg).

$>\mathbf{2 0 0 6}$ - The information about the "model of hips' movements" and type of scoliosis.

$>2007$ - Description of additional indirect influences (extension contracture of spine in infants, laxity of joints and anterior tilt of pelvis) origination in CNS in the course of the development of scoliosis and answer to the question why blind children do not have scoliosis.

\subsection{There are following steps in the development of scoliosis}

$1 /$ asymmetry in hips' movements connected with SofCD,

$2 /$ further influence is connected with walking and standing 'at ease' on the right leg.

The explanation: while walking the restricted movement of the right hip is transmitted to the pelvis and to the spine and causes rotation deformity and results in stiffness of the spine.

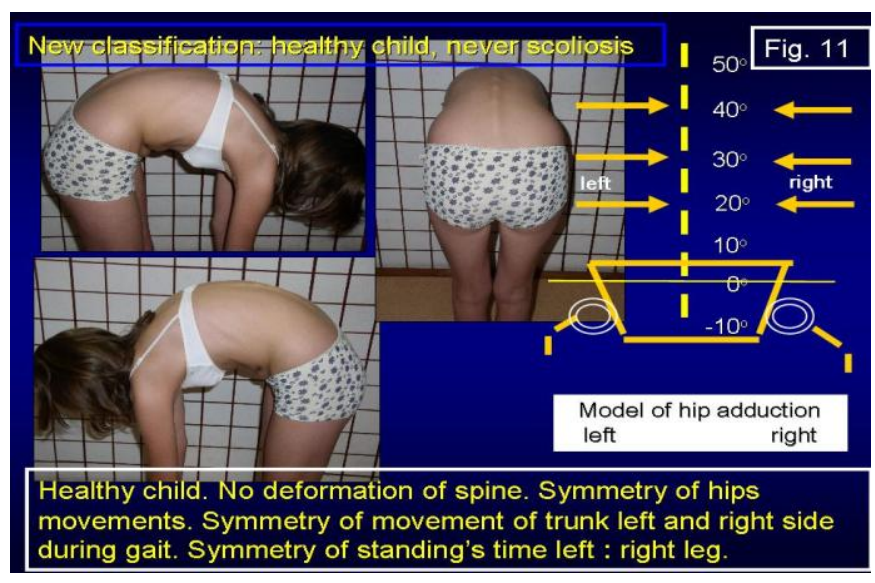

Fig. 11. A healthy child. No deformity of the spine. Symmetry of hips movements. Symmetry of movement of the trunk on the left side and the right side during gait. Symmetry of duration of standing on the left leg and on the right leg. No biomechanical influence on the spine growth.

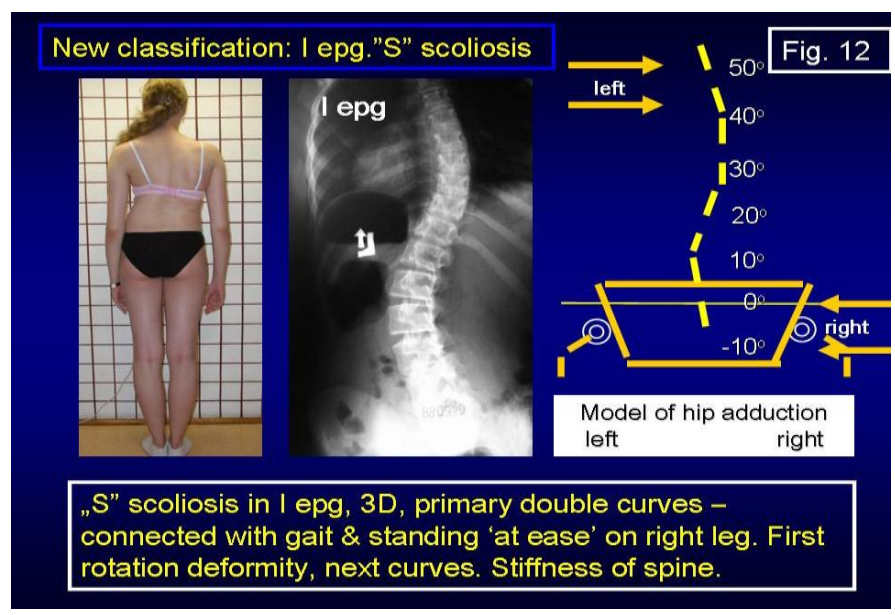

Fig. 12 „S” scoliosis in I epg, 3D, primary double curves - connected with gait \& standing 'at ease' on right leg. First rotation deformity and stiffness of the spine appears, then curves. This type of scoliosis with progression 
The next cause is connected with permanent standing 'at ease' on the right leg. The new classification of the socalled idiopathic scoliosis provides three groups and four types of spine deformity (Fig. 12, 13, 14).

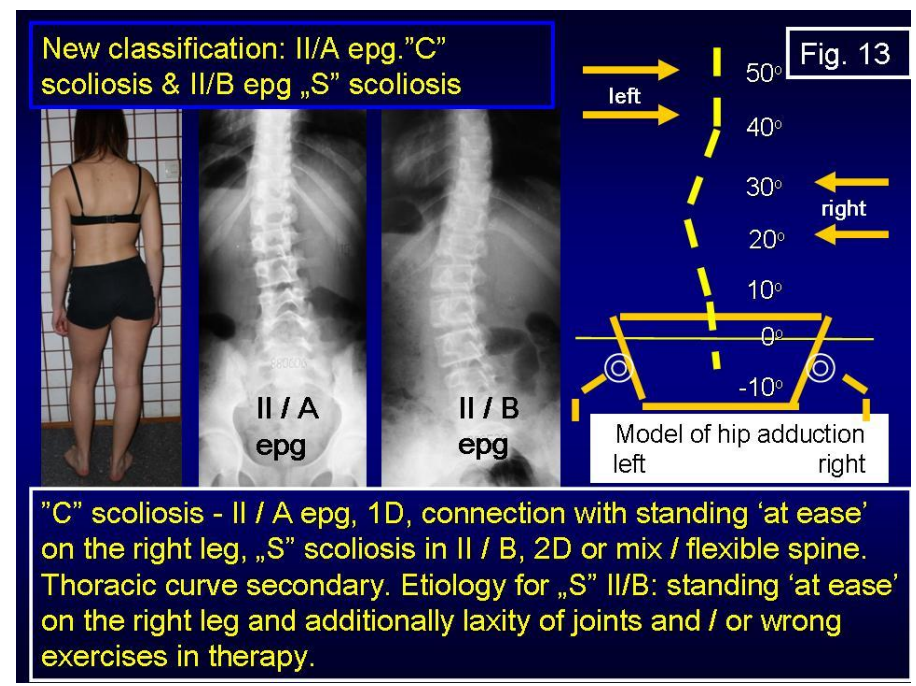

Fig. 13. "C" scoliosis - II / A epg, ID. Causal factor: standing 'at ease' on the right leg, ,"S" scoliosis in II / B, $2 D$ or mix / flexible spine. Thoracic curve is secondary. Aetiology for ,S" II/B: standing 'at ease' on the right leg and additional laxity of joints and / or wrong exercises in therapy.

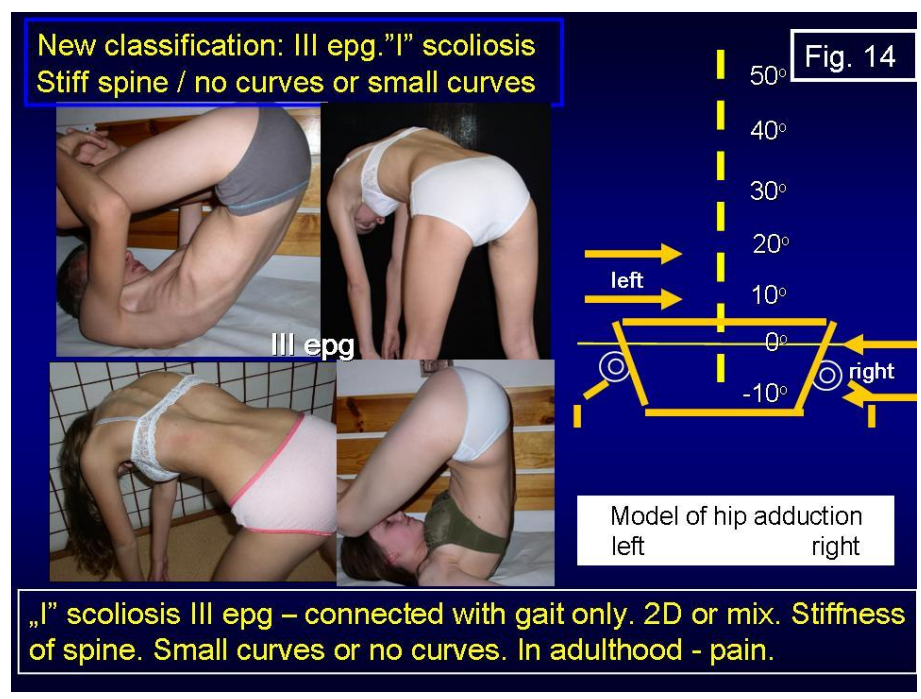

Fig. 14. I" scoliosis III epg - connected with gait only. 2D or mix. Stiffness of the spine. Small curves or no curves. In adults - (back)pain.

In situation of symmetry of movement of hips - do not exist any scoliosis (Fig. 11). We explain also, that the "infantile scoliosis" is not so called idiopathic scoliosis (Fig. 10).

In the course of therapy of every types of scoliosis only one type of exercise is proper, namely stretching, never strengthening exercises.

\section{CONCLUSIONS}

1/ Every paediatric orthopaedic surgeon and paediatric doctor as well every physiotherapist should be familiarized with knowledge about the "Syndrome of Contractures and Deformities" (SofCD) according Prof. Hans Mau,

2/ All newborns and babies with SofCD should undergo an early treatment of proper nurseling, of using proper orthopaedic devices. In the case of older children stretching exercises aiming at the symmetry of joints' movements should be introduces. In some cases a operative procedure is necessary. 
3/ Treatment of small children with "residual / slight changes of SofCD" should be introduced as an effective prophylaxis of movement insufficiency of knees, hips and spine in adults.

4/ The aim of physiotherapy in the cases of problems in hips, neck, spine is to achieve symmetry of position, symmetry of movement of joints and also symmetry of function.

5/ In our Department we never advised the performance of strengthening exercises, but only stretching exercises in order to eliminate the contracted (shortened) tissues in the region of joints.

6/ Additionally thermotherapy, magnetic fields, biodynamic (diadymanic), laser, massage are used in the course of treatment.

\section{REFERENCES}

[1] Barlow T.G. Early diagnosis and treatment of congenital dislocation of the hip, J,.B.J.S. 962, 44-B (2), 292 - 3012

[2] Cheng JC, Tang SP, Chen TM, et al. The clinical presentation and outcome of treatment of congenital muscular torticollis in infants: a study of 1,086 cases. J Pediatr Surg 2000;35:1091-6.

[3] Dega W. Bada ia z dziedziny etiologii wrodzonego zwichnięcia biodra. Chir. Narz. Ruchu, 1932, 144

[4] Green N.E., Griffin P.P. Hip dysplasia associated with abduction contracture of the contra lateral hip, J.B.J.S. 1982, 63-A, $1273-1281$

[5] Golden KA, Beals SP, Littlefield TR, et al. Sternocleidomastoid imbalance versus congenital muscular torticollis: their relationship to positional plagiocephaly. Cleft Palate Craniofac J 1999;36:256-61.

[6] Hensinger R.N. Congenital dislocation of the hip. Clinical Symp. 1979, 31

[7] Howorth B. The etiology of congenital dislocation of the hip, Clic. Orthop. 1977, 29, $164-179$

[8] Kane AA, Mitchell LE, Craven KP, et al. Observations on a recent increase in plagiocephaly without synostosis. Pediatrics 1996;97:877-85.

[9] Kałakucki Jarosław, Jacek Karski, Mariusz Długosz, Tomasz Karski. "Science and opinion - knowledge and ignorance (Hippocrates) on examples in pediatric orthopedics". Wry neck (torticollis myogenes), Perthes disease, "anterior tilt of pelvis" in children and youth and "spine pain syndrome" in adults (P. 3). Pohyb. Ustr. / Czech Republic, 2008 R. 16 č. $3 / 4$ suppl., s. 283-286.

[10] Karski Tomasz, Jarosław Kałakucki, Jacek Karski. Relationship of "syndrome of contractures" in newborns with the development of the so-called idiopathic scoliosis, World J. Pediatr. / China, 2007 vol. 3 nr 4, s. 254-259, bibliogr. poz. 38.

[11] Karski Tomasz, Jacek Karski, Jarosław Kałakucki. Minimal incongruence of the hip joint at youth and adults treated and not-treated because of DDH in baby period. W: Second Annual International Conference SICOT/SIROT 2003. Cairo, September 10-13, 2003. Abstr, [b. pag.] SFS8-H.

[12] Karski Jacek, Tomasz Karski: "Zespół przykurczów" u noworodków i niemowląt przyczyną odległych dysfunkcji narządu ruchu w tym skolioz tzw. idiopatycznych. Wykrywanie zagrożeń oraz zasady profilaktyki przez zabiegi fizjoterapeutyczne. ("Syndrome of contractures" in newborns and babies as a cause of deformities in movement apparatus and in etiology of the so-called idiopathic scoliosis in next years of life. New screening and treatment by physiotherapy.) Zesz. Nauk. WSSP 2012 t. 15, s. 11-25, bibliogr. poz. 43, sum.

[13] Karski Tomasz, Maria Frelek-Karska, Jacek Karski, Jacek Madej, Jaroslaw Kalakucki: "Zespół przykurczów" u noworodków i niemowląt przyczyną odległych dysfunkcji narządu ruchu w tym tzw. skolioz idiopatycznych. Wykrywanie zagrożeń nieprawidłowego rozwoju kręgosłupa i zasady nowej profilaktyki skolioz. (The syndrome of contractures' at newborns and babies as a cause of dysfunctions of skeletal system and among others of the so-called idiotaphic scoliosis. The discovery of the danger of the oncoming scoliosis. Rules of new prophylactics.) W: Międzynarodowa Konferencja Naukowa: "Uwarunkowania rozwoju sprawności i zdrowia". Częstochowa, 10-11 grudnia 2001. Progr. i streszcz, s. 11-12.

[14] Karski Jacek, Tomasz Karski, Marta Tarczyńska, Jarosław Kałakucki: Zespół przykurczów u noworodków i niemowląt wg prof. Hansa Mau w wyjaśnieniu "geografii" i klinicznych cech skolioz tzw. idiopatycznych. Ortop. Traumatol. Rehabil. 2004 vol. 6 Suppl. 1, s. 31.

[15] Karski Jacek, Tomasz Karski, Grzegorz Kandzierski, Marta Tarczyńska, Jarosław Kałakucki, Michał Latalski : "Zespół przykurczów" u noworodków i niemowląt wg prof. Hansa Mau w wyjaśnieniu "geografii" i niektórych klinicznych cech skolioz tzw. idiopatycznych. ("Contracture syndrome" in newborns and infants according to Prof. Hans Mau as an explanation of the "geography" and certain clinical features of idiopathic scoliosis). Ortop. Traumatol. Rehabil. 2005 vol. 7 nr 1, s. 23-27, bibliogr. sum.

[16] Karski Jacek, Jaroslaw Kalakucki, Tomasz Karski, Mariusz Dlugosz "Syndrome of contractures" (according to Mau) with the abduction contracture of the right hip as causative factor for development of the so-called idiopathic scoliosis. ("Syndrom kontraktur" (podle Mau) s abdukční kontrakturou pravého kyčelního kloubu jako př́íčnného faktoru vývoje tzv. idiopatické skoliózy). Pohyb. Ustr. / Czech Republic, 2006 R. 13 č. 1/2, s. 81-88, bibliogr. poz. 21. 
American Research Journal of Medicine And Surgery, Volume 1, Issue 2, 2015

ISSN 2379-8955

[17] Karski Tomasz, Jarosław Kałakucki, Jacek Karski: "Syndrome of contractures" (according to Mau) with the abduction contracture of the right hip as causative factor for development of the so-called idiopathic scoliosis.W: Technology and informatics vol. 123 Research into spinal deformities 5 Ed. D. Uyttendaele, P.H. Dangerfield, Washington, 2006, IOS Press, s. 34-39, bibliogr. poz. 21.

[18] Karski Jacek, Tomasz Karski, Zbigniew Kędzierski: "Syndrome of contractures and deformities" in newborns and infants according Mau - and its influence for secondary deformities of movement apparatus in babies, youth and adults. Pohyb. Ustr. 2013 R. 20 č. 3/4 suppl., s. 315-317

[19] Mau Hans. Aetiopathogenese von Skoliose, Hüftdysplasie und Schiefhals in Säuglingsalter, Zeitschrift f. Orthop. 1979, 5, 6-1-605

[20] Rogers GF, Mulliken JB. The significance of torticollis in deformational posterior plagiocephaly [abstract]. Proceedings of the Tenth International Congress of the International Society of Craniofacial Surgery 2003;61.

[21] Watson GH. Relation between side of plagiocephaly, dislocation of hip, scoliosis, ba tears, and sternomastoid tumours. Arch Dis Child 1971;46:203-10.

[22] www.ortopedia.karski.lublin.pl 